\title{
Long-Term Effect of Lophodermium Needle Cast on The Growth of Scots Pine and Implications for Financial Outcomes
}

\author{
Āris Jansons ${ }^{1,2, *}$, Pauls Zeltin̦š ${ }^{1,2} \mathbb{D}$, Jānis Donis ${ }^{1}$ and Una Neimane ${ }^{1}$ \\ 1 Latvian State Forest Research Institute Silava, Rīgas Street 111, LV-2169 Salaspils, Latvia; \\ pauls.zeltins@silava.lv (P.Z.); janis.donis@silava.lv (J.D.); una.neimane@silava.lv (U.N.) \\ 2 Institute of Forestry and Rural Engineering, Estonian University of Life Sciences, \\ Kreutzwaldi 5, 51014 Tartu, Estonia \\ * Correspondence: aris.jansons@silava.lv
}

Received: 24 May 2020; Accepted: 25 June 2020; Published: 29 June 2020

\begin{abstract}
In Northern Europe, climate change may facilitate the prevalence of Scots pine, yet also promote the spread of pathogens attacking this species. A common biotic risk for Scots pine in nurseries and young stands is Lophodermium needle cast, primarily caused by Lophodermium seditiosum, which negatively affects the survival and growth of saplings. Reduced tree growth has been observed several years after damage by Lophodermium needle cast. However, for decision-making in protection or resistance breeding, an estimate of financial loss is important. Thus, the study aimed to assess the long-term influence of Lophodermium needle cast on the growth and financial value of Scots pine stands. The effect of needle cast damage during the sixth growing season on growth at the age of 17 years was evaluated in a control-crossed Scots pine progeny trial, and the results indicated a significantly negative effect on the height and diameter of the trees. A significant family effect also existed on the severity of the needle cast damage. Long-term simulations indicated that severely damaged Scots pines had a reduced equivalent annual annuity (EAA) of almost $100 \%$ at the final harvest. More intensive early management to reduce stand density could partly compensate for losses caused by needle cast. A higher EAA for the most resistant group of trees regardless of the stand management scenarios suggests an economically justified potential for improved resistance. Strong negative $(-0.62$ to -0.70$)$ correlations of height and survival with the proportion of severely affected trees at the family mean level implies that resistant genotypes can be selected along with improved growth in progeny trials, which are affected by needle cast.
\end{abstract}

Keywords: tree resistance; Scots pine pathogens; biotic risks; financial analysis; equal annual annuity; tree breeding

\section{Introduction}

In the hemiboreal regions of Europe, climate change can lead to an increased share of Scots pine (Pinus sylvestris L.), substituting for other tree species, such as Norway spruce Picea abies (L.) H. Karst. [1]. Nevertheless, Pinus spp. also have potential risks. They are more susceptible to needle cast and needle blight than other conifers [2,3]. Climate change has a direct influence on both trees and pathogens, and the interactions between them, resulting in changed disease effects and more frequent and severe attacks [4-8]. Since the 1990s, several severe outbreaks of Lophodermium needle cast caused by Lophodermium seditiosum in the Baltic region, Poland, and Fennoscandia have occurred, and it is still one of the most common needle diseases of pines [9-14].

Lophodermium is a complex fungal genus consisting of both needle endophytes and pathogens. The pathogenicity of L. seditiosum has been demonstrated in vivo [15], and it causes needle loss of young pines in nurseries and forest stands $[3,11,16]$. Trees retain needles for several years; however, 
older needles are less photosynthetically active than younger ones [17]. Thus, a current year needle infection leads to reduced growth (annual increment) and survival [18]. Moreover, biotic disturbances may interact with each other [19], and the damage to forest stands could be the result of a complex of infections. For instance, the outbreak of L. seditiosum in Estonia coincided with the serious spread of Dothistroma septosporum [7,12]. The severity of Lophodermium needle cast damage decreases with age, and trees older than 10 years are rarely infected [3]. Nevertheless, growth reduction related to the defoliation caused by Lophodermium needle cast can last several years after the attack [20].

The trees' genetic response and adaptability to new climate conditions are slower than those of the pathogens $[6,21]$. As a result, pathogens can increasingly reduce the monetary value of forests. Therefore, management practice might be reconsidered and altered to mitigate the effect of pathogens on forest stands [22]. Although disease by itself ensures natural selection [23] and fungicides may be an effective method of preventing forest diseases in nurseries $[6,16,24]$, resistance against fungal pathogens could be included in breeding programmes [6,25-29], thus preventing severe damage and providing improved yield and stem quality. Genetic effects on the resistance to Lophodermium needle cast have been indicated [3,30-33].

Information on the longer-term effects of Lophodermium needle cast is important to project timber and financial losses across the rotation period and evaluate alternative management scenarios to mitigate risks. Nevertheless, most studies in European forests have focused on natural disturbances, such as wind, fire, and (to some extent) pests, while the effects of pathogens have been relatively little studied [34-39]. In addition, economic analysis of natural forest disturbances to a large extent had focused on wildfires [19] but the long-term effects of fungal pathogens, including Lophodermium needle cast, on forest management profitability have been sparsely analysed. Therefore, the aim of this study, based on the progeny trial information, is to assess the long-term influence of Lophodermium needle cast on the growth and financial value of Scots pine stands.

\section{Materials and Methods}

\subsection{Study Material}

The study was conducted in a Scots pine control crossing progeny trial established in the eastern part of Latvia near Kalsnava $\left(56^{\circ} 40^{\prime} \mathrm{N}, 25^{\circ} 57^{\prime} \mathrm{E}\right)$. The control crosses were done using 10 clones of local (Latvian) origin. In total, 98 full-sib families were obtained and represented in the trial. The trial was established on rather poor, sandy soil corresponding to the Vacciniosa forest type [40], and the trees were planted in four replicates of 15-tree-block-plots for each family with a planting density of 5000 trees ha ${ }^{-1}$ (spacing $2 \times 1 \mathrm{~m}$ ). In total, 4154 initial planting spots were available for analysis, since some families were not present in all four replications and some plots were excluded from analysis due to low initial survival shortly after planting.

In the trial, needle cast infestation may have originated from the surrounding mature and young Scots pine stands. Needle cast symptoms caused by Lophodermium spp. were identified by a single observer using the macroscopic features of the fungus [15]. The damage was assessed in June of the sixth growing season by visually evaluating a proportion of the needles on the last height increment, which was infected at the end of the previous growing season and thus turned yellow then brown during the given season (at the time of the assessment). The needle cast damage assessment was done on a five-grade scale typically used in local nurseries and progeny trials according to the proportion of damaged needles: Grade 1 corresponds to $0 \%$ to $5 \%$, Grade 2 to $6 \%$ to $35 \%$, Grade 3 to $36 \%$ to $65 \%$, Grade 4 to $66 \%$ to $95 \%$, and Grade 5 to $96 \%$ to $100 \%$ of the damaged needles. For the analysis of the family mean level, the proportion of severely damaged trees was used, corresponding to the pooled proportion of the trees in Grades 4 and 5 . The tree height $( \pm 0.01 \mathrm{~m})$ and diameter of the root collar $( \pm 0.001 \mathrm{~m})$ at the age of 5 years, and the tree height $( \pm 0.1 \mathrm{~m})$ and stem diameter at breast height $(\mathrm{DBH}$ $\pm 0.001 \mathrm{~m})$ at the age of 17 years were measured. 


\subsection{Statistical Analysis}

The Chi-square test was used to assess the differences in the distribution of the damage grades between trees that died at the age of 6-17 years and trees that survived until the age of 17 years. Considering the experimental design, the family effect on the damage grade was assessed using a generalised linear mixed-effect model applying the Poisson distribution:

$$
y_{i j k l}=\mu+F_{i}+r_{j}+p_{k}+\varepsilon_{i j k l}
$$

where $y_{i j k l}$ is the response variable (damage grade) of the $l$ th tree from the $i$ th family in the $k$ th multiple-tree plot nested within the $j$ th replication, $\mu$ is the overall mean, $F_{i}$ is the fixed effect of the $i$ th family, $r_{j}$ is the random effect of the $j$ th replication, $p_{k}$ is the random effect of the $k$ th plot, and $\varepsilon_{i j k l}$ is the residual error.

At the individual tree level, the effect of the family and damage grade at the time of the first height measurements on the tree height and diameter at the repeated height measurements was assessed with a linear mixed-effect model, using the tree height or diameter at the first measurement as a covariate:

$$
y_{i j k l m}=\mu+M_{i j k l m}+D_{i}+F_{j}+M_{i j k l m} D_{i}+M_{i j k l} F_{j}+D_{i} F_{j}+r_{k}+p_{l}+\varepsilon_{i j k l m}
$$

where $y_{i j k l m}$ is the response variable (height or diameter at the age of 17 years) of the $m$ th tree with the $i$ th needle cast damage grade from the $j$ th family in the $l$ th multiple-tree plot nested within the $k$ th replication, $M_{i j k l m}$ is the fixed effect of the initial measurement at the age of 5 years, $D_{i}$ is the fixed effect of the $i$ th damage grade, $F_{j}$ is the fixed effect of $j$ th family, $M_{i j k l m} D_{i}$ is the interaction of the first measurement and damage grade, $M_{i j k l m} F_{j}$ is the interaction of the first measurement and family, $D_{i} F_{j}$ is the interaction of damage grade and family, $r_{k}$ is the random effect of the $k$ th replication, $p_{l}$ is the random effect of the $l$ th plot, and $\varepsilon_{i j k l m}$ is the residual error. Pearson's correlation was used to assess relations between traits (tree height and diameter, proportion of severely damaged trees, and survival) at the family mean level. All tests were performed and all data analyses were conducted in R (v. 3.6.1) with $95 \%$ confidence interval $(\alpha=0.05)$ [41].

\subsection{Evaluation of the Financial Outcome}

The financial value at the final harvest was estimated from five-year period simulations in which the tree dimensions at a certain age were obtained using the local growth models (Supplement 1) [42]. Regarding the small number of trees corresponding to grades 1 and 5, simulations were done for each of three pooled damage grade groups (grade 1 to 2 , grade 3 , and grade 4 to 5 ), using group mean values of height, DBH, number of trees, and basal area at the age of 17 years as input data. No modifications in models were applied for different damage grades.

In simulations, three stand densities at the age of 17 years were used as input: the actual density (1930 to 3900 trees ha ${ }^{-1}$ ), 1400 (intensive management regime), and 2500 (conventional management regime) tallest trees $\mathrm{ha}^{-1}$. For each damage grade group, three different commercial thinning regimes were applied in the simulations: (i) thinning done when the relative stand density reaches 0.95 and is reduced to 0.7, (ii) thinning done when the relative stand density reaches 0.95 and is reduced to 0.60 , and (iii) no thinning applied (Table S1). The analysis was applied for two final harvest scenarios: (i) when the cutting age (101 years) or (ii) target diameter $(\geq 35 \mathrm{~cm})$ was reached according to the current legislation in Latvia.

The volume of the logs was determined from the tree assortments in the stand according to the local equation [43]. Income from the harvest was calculated from the volume and prices (Central Statistical Bureau of Latvia 2018) of the assortments (Tables S2 and S3) [44]. To reflect the sensitivity to the situation in the timber market, income was estimated for three price levels-average, minimum, and maximum price (Table S3). 
The financial value of the stands was calculated using the equivalent annual annuity (EAA) with $2 \%, 3 \%$, and $4 \%$ interest rates [45]:

$$
E A A=\frac{r * \sum_{t=1}^{n} \frac{R_{t}}{(1+r)^{n * 5}}}{1-(1+r)^{-n * 5}}
$$

where $r$ is the interest rate (\%), $R_{t}$ is the net cash inflow-outflow during a single period $t$ (EUR), and $n$ is the number of five-year periods. Differences in EAA among groups with various damage grades were estimated using the analysis of variance and post-hoc Tukey's test.

\section{Results}

In the study trial, the survival of trees was $81 \%$ (3373 out of 4154 ) at the age of five years, and $54 \%$ at the age of 17 years. In the sixth growing season, $52 \%$ of trees had the damage grade 4 and 5 ( $>66 \%$ damaged needles). The proportion of trees in the damage grades differed significantly $(p<0.01)$ between trees that survived until the age of 17 years and trees that died at the age of 6 to 17 years (Figure 1). By the age of 17 years, more severely defoliated trees had died than less damaged trees.

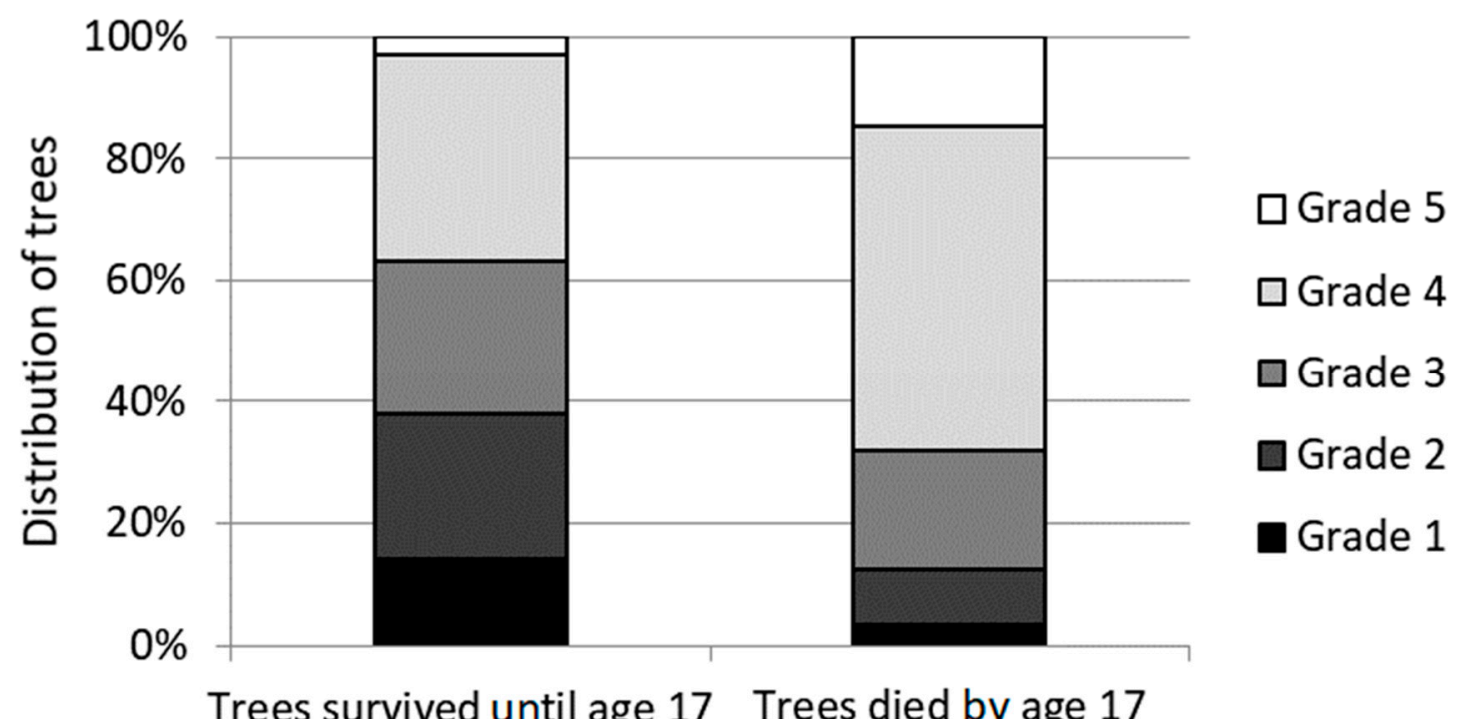

Figure 1. Tree distribution among the needle cast damage grades (1-5) for trees that survived until the age of 17 years and trees that died at the age of 6 to 17 years.

\subsection{Needle Cast Effect on Scots Pine Growth}

At the age of five years, the mean values $\pm 95 \%$ confidence intervals of the tree height and diameter at the root collar were $130 \pm 1.0 \mathrm{~cm}$ and $25 \pm 0.2 \mathrm{~mm}$, respectively. At the age of 17 years, corresponding values of tree height and DBH were $8 \pm 0.1 \mathrm{~m}$ and $9 \pm 0.1 \mathrm{~cm}$, respectively. The tree dimensions among the damage grades differed significantly, with less-damaged trees being significantly $(p<0.05)$ higher than more-damaged trees (Figure 2).

At the individual tree level, the height at the age of 17 years was affected by the height at the age of five years, damage grade, and family (all $p<0.01$ ). There was also a statistically significant interaction between the height at the age of five years and the family $(p=0.02)$. For DBH at the age of 17 years, the root-collar diameter at the age of five years and the damage grade were the only significant factors $(p<0.01)$. Trees less damaged by needle cast in the sixth growing season were higher at the age of 17 years. Trees that were initially (at the age of five years) high but less resistant to damage were shorter after 12 years than trees that were initially shorter but resistant to damage. A more pronounced decrease in the number of trees was found for initially shorter trees that simultaneously had a higher damage grade. Initially shorter trees included a lower proportion of undamaged trees. 


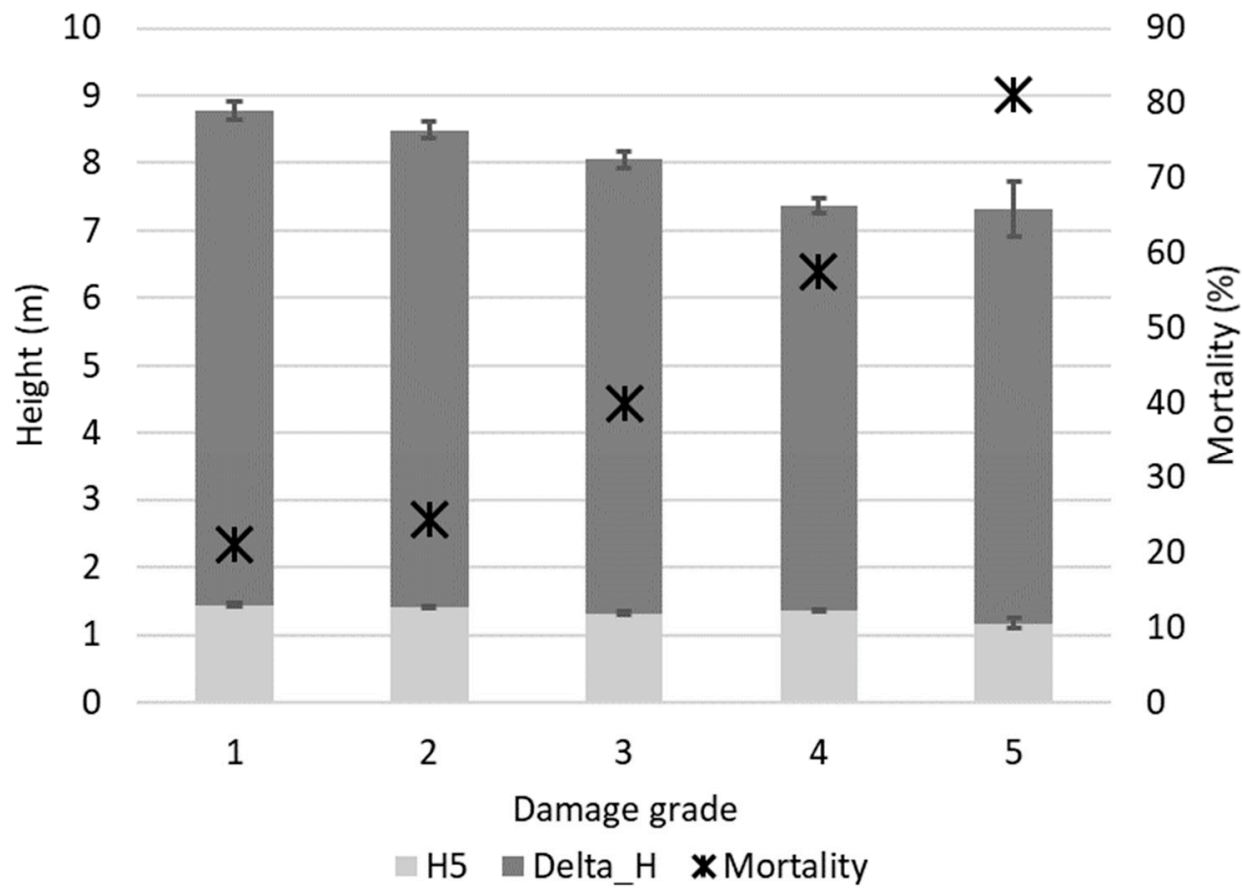

Figure 2. Tree height at the age of five years (H5), height increment between the age of 5 and 17 years (Delta_H), and mortality (\%) between the age of 5 and 17 years. Whiskers denote $95 \%$ confidence interval.

The full-sib family had a statistically significant effect on the damage grade $(p<0.01)$. At the family mean level, the relation between the proportion of severely damaged trees and growth traits (height and diameter at both ages) was negative (Table 1, Figure 3; $p<0.05 ; r=-0.25$ to -0.62 ). No relation was found between the proportion of damaged trees and survival at the age of five years (i.e., until the assessment of the needle cast damage), yet the relation between the proportion of severely damaged trees and the survival at the age of 6 to 17 years was strong and negative (Table $1 ; r=-0.70, p<0.001$ ).

Table 1. Survival, tree dimensions, and correlation coefficients between these traits and the proportion of severely damaged trees (pooled grades 4 and 5) at the family mean level.

\begin{tabular}{|c|c|c|c|}
\hline \multirow[t]{2}{*}{ Trait } & \multirow[t]{2}{*}{$\begin{array}{l}\text { Correlation Coefficient with the } \\
\text { Proportion of Severely Damaged Trees }\end{array}$} & \multicolumn{2}{|c|}{$\begin{array}{c}\text { Range of Family Mean Values }( \pm 95 \% \\
\text { Confidence Interval) }\end{array}$} \\
\hline & & Minimum & Maximum \\
\hline Survival at the age of 5 years (\%) & -0.07 & 43 & 100 \\
\hline $\begin{array}{l}\text { Survival at the age of } 17 \text { years } \\
\text { relative to that at age } 5(\%)\end{array}$ & $-0.70^{* * *}$ & 6 & 96 \\
\hline Height at the age of 5 years $(\mathrm{cm})$ & $-0.25^{*}$ & $103 \pm 10.1$ & $157 \pm 13.4$ \\
\hline $\begin{array}{l}\text { Diameter of the root collar at the age } \\
\text { of } 5 \text { years }(\mathrm{mm})\end{array}$ & $-0.37^{* * *}$ & $20 \pm 1.8$ & $32 \pm 2.2$ \\
\hline Height at the age of 17 years (m) & $-0.62^{* * *}$ & $6 \pm 1.3$ & $10 \pm 0.5$ \\
\hline $\begin{array}{c}\text { Stem diameter at the breast height at } \\
\text { the age of } 17 \text { years }(\mathrm{cm})\end{array}$ & $-0.40^{* * *}$ & $7 \pm 1.3$ & $12 \pm 2.9$ \\
\hline
\end{tabular}

${ }^{1}$ Proportion of trees evaluated as grades 4 and 5 relative to the number of trees at the age of five years; ${ }^{*} p<0.05$,

*** $p<0.001$. 


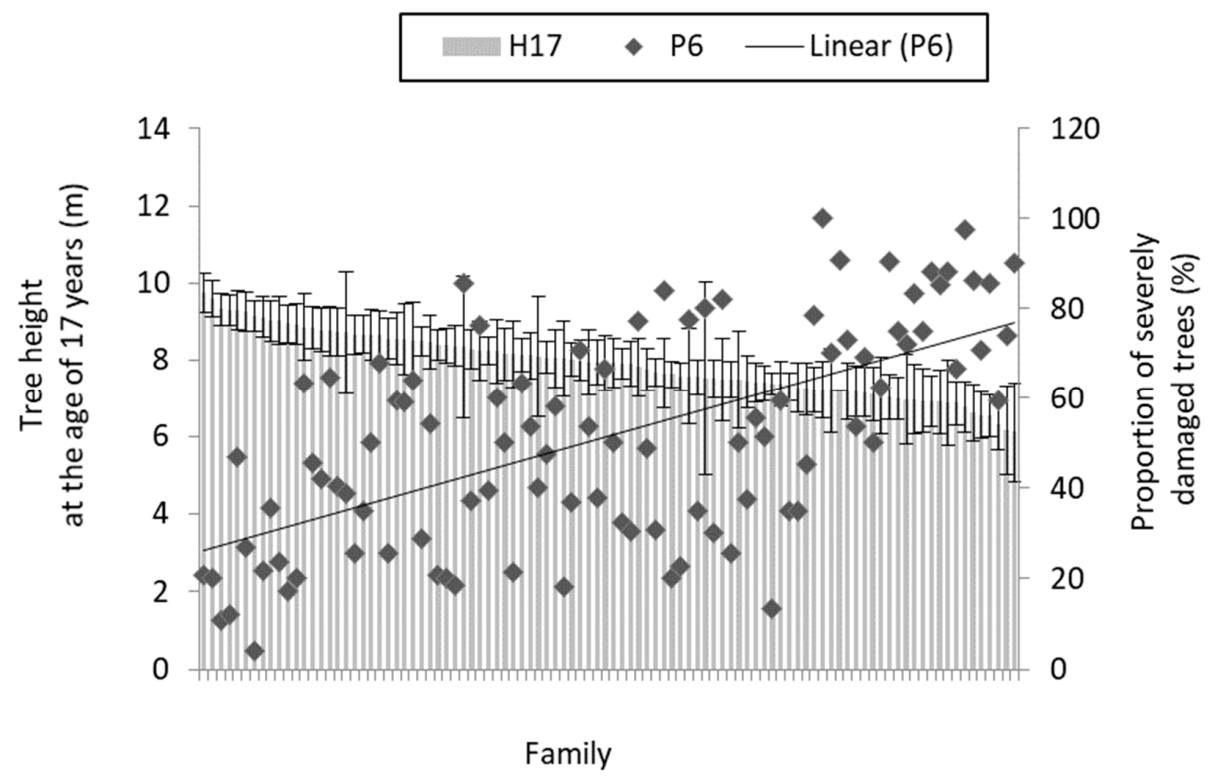

Figure 3. The relation between tree height at the age of 17 years (H17) and proportion of severely damaged (pooled grades 4 and 5) trees in the sixth growing season (P6) at the family mean level (families ordered descending according to mean height). Whiskers denote $95 \%$ confidence intervals.

\subsection{Long-Term Effects on Financial Value}

Simulation results indicated a significant $(p<0.01)$ effect of needle cast damage on EAA. At both the target age (101 years) and target DBH ( $\geq 35 \mathrm{~cm}$ ), the seriously damaged (grades 4 to 5) group of Scots pine had a significantly lower EAA than the group of undamaged or slightly damaged (grades 1 to 2 ) trees, regardless of the density at the age of 17 years, commercial thinning regime, or price level (Figure 4, Table S4). For all damage levels, EAA at the final harvest according to the target DBH was more than double compared to the target age of 101 years. The target DBH for grades 1 to 2, 3, and 4 to 5 were reached on average at the age of 64,77 , and 97 years, respectively. The mean EAA reached $62.3 \pm 18.7$ EUR ha ${ }^{-1}$ for damage grades 1 to 2 at the final harvest time according to the target $\mathrm{DBH}$, whereas it was lowest $\left(0.8 \pm 9.4 \mathrm{EUR} \mathrm{ha}^{-1}\right)$ for trees with grades 4 to 5 at the conventional final harvest time (Figure 4$)$.

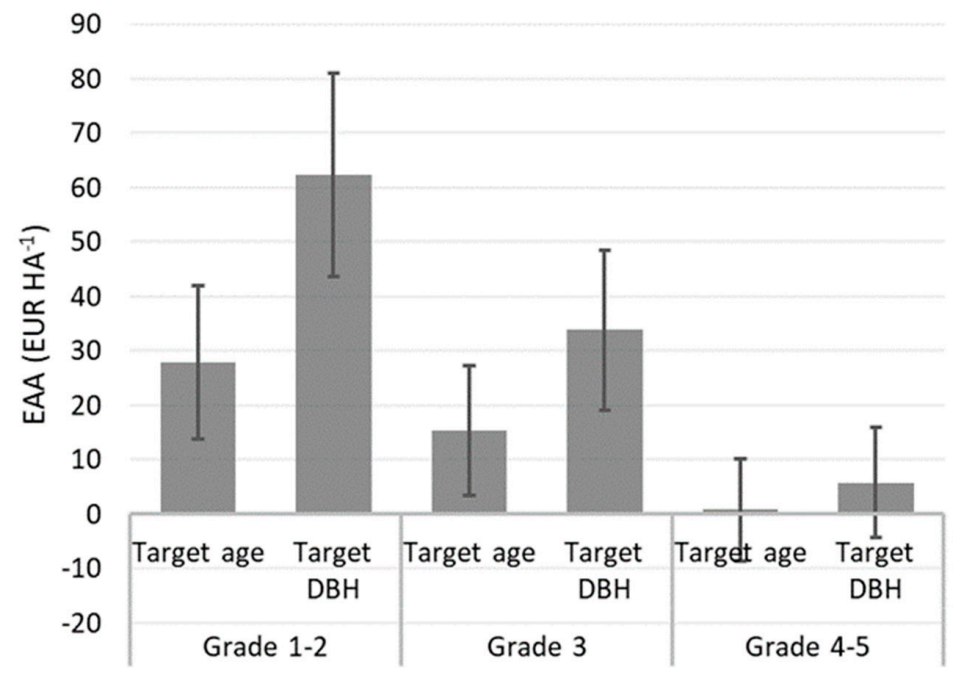

Figure 4. Average equal annual annuity (EAA, EUR ha ${ }^{-1}$ ) applying $2 \%, 3 \%$ and $4 \%$ interest rates for different needle cast damage groups at two final harvest scenarios: cutting according to target age (101 years) or when the minimum allowable diameter at breast height (DBH) is greater than or equal to $35 \mathrm{~cm}$. Whiskers denote $95 \%$ confidence intervals. 
In all simulated scenarios, the EAA reached the peak at the age of 35 to 45 , tending to culminate earlier for groups with less needle cast damage and lower stand density at the age of 17 years (Figure 5). Regarding different commercial thinning regimes, the highest EAA for all groups was reached by applying a moderate commercial thinning regime, when relative density is reduced from 0.95 to 0.70 (Table S4). When applying a rate of $4 \%$, the calculations for all price levels showed a similar tendency of EAA dynamics. The highest EAA during the simulated period was for the least damaged trees (grades 1 to 2) with a density of 1400 trees ha ${ }^{-1}$ at the age of 17 years, whereas the lowest EAA was estimated for seriously damaged trees in the actual density scenario (1930 trees ha ${ }^{-1}$ ), reaching positive values only at the maximum price level. For all needle cast damage levels, EAA was lower for the higher initial density at the age of 17 years compared to the intensive early management scenario (Table S4). Nevertheless, all scenarios applying a rate of $4 \%$ had a negative EAA at the minimum price level, whereas the scenarios with lower density at the age of 17 years for groups with grades 1 to 3 showed a stable tendency to maintain positive EAA during the simulation period for the average and maximum price levels.

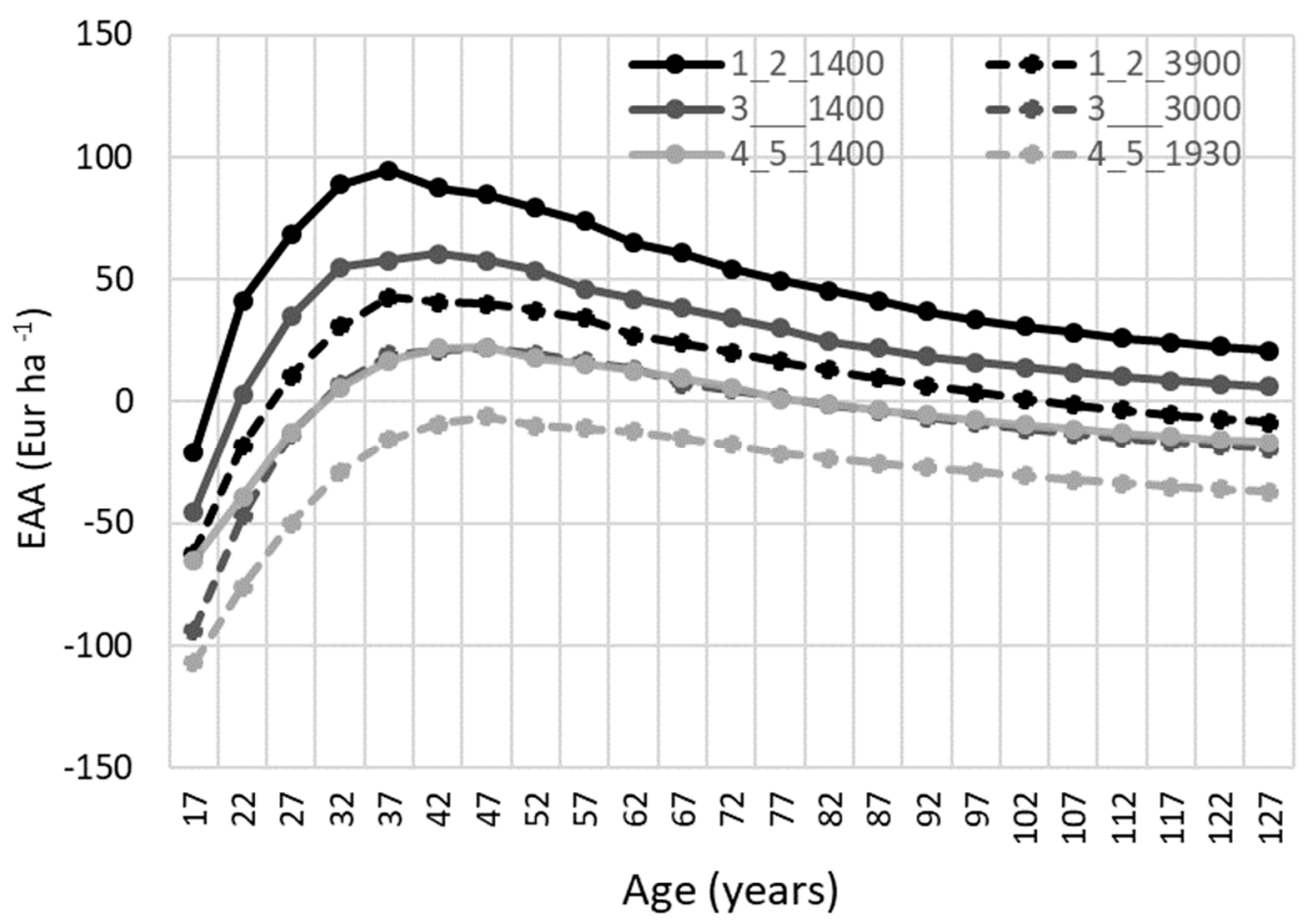

Figure 5. Equivalent annual annuity (EAA) dynamics with an interest rate of $4 \%$ for different initial densities (1400 trees $\mathrm{ha}^{-1}$ and actual density at the age of 17 years) and damage grades applying thinning regime 1 (reducing relative stand density from 0.95 to 0.70 ). Simulated scenarios: 1_2_1400: damage grades 1 to 2 with a density of 1400 trees ha ${ }^{-1} ; 1 \_2 \_3900$ : damage grades 1 to 2 with a density of 3900 trees ha ${ }^{-1}$; 3_1400: damage grade 3 with a density of 1400 trees ha ${ }^{-1}, 3$ _3000: damage grade 3 with a density of 3000 trees ha ${ }^{-1}, 4 \_5 \_1400$ : damage grades 4 to 5 with a density of 1400 trees $^{-1}$, and 4_5_1930: damage grades 4 to 5 with a density of 1930 trees ha ${ }^{-1}$.

\section{Discussion}

Severe defoliation due to L. seditiosum infection is a common type of damage that affects Scots pine in nurseries and young stands in the Baltic sea region $[11,18,20,23,31,46]$. In our study trial, more than half of the trees were severely damaged by Lophodermium needle cast in the sixth growing season, yet damage had likely occurred for several years. The magnitude of the damage may vary substantially among locations [31], due to the irregularity and high dependence on climatic factors [47]. An Estonian study concluded that the total precipitation from May to August of at least $300 \mathrm{~mm}$ 
indicated a potential epidemic the next year [20]. Induced by the changing climate, milder winters are also reported as a causal factor for increased needle cast damage [11]. Overall, the risks of fungal pathogens, such as L. seditiosum, are increasing with environmental changes towards higher humidity and temperatures [48].

We observed a significantly different proportion of trees in the different damage grades for individuals that survived and died at the age of 6 to 17 years, with the latter group being more affected by L. seditiosum (Figure 1). A four-times higher mortality rate between the age of 5 and 17 years for a group of severely damaged than minorly damaged trees (ca. $20 \%$ and $80 \%$, respectively) indicated a substantial negative impact on survival (Figure 2). Although the loss of dead needles could not necessarily be a direct cause of death for the infected tree, seedlings had reduced viability and weakened new shoots [13,15], thus becoming more susceptible to other abiotic and biotic risks [18]. Needle cast damage is also reported to negatively affect survival in open-pollinated progeny trials, where the mortality of severely damaged trees reached $85 \%$ at the age of 12 years [18].

Loss of actively assimilating foliage and nutrients in the shedding needles reduces tree growth [49]. Our results indicated significant differences in height and DBH among trees with different needle cast damage severity, with less-damaged trees having a clear tendency to become larger at both individual and family man level (Figure 2 and Table 1). Both height and DBH at the age of 17 years depended on the initial height at the age of five years; however, the resistance to needle cast seemed to have a stronger effect. As a result, the growth of initially smaller but more-resistant trees after 12 years surpassed the dimensions of the trees that were initially larger but less resistant. The height of Scots pine saplings at the age of 12 years was reported to be negatively affected by cumulative needle cast damage during the fourth to sixth growing seasons [18]. The three youngest needle sets reported to have a significant influence on the current year's height and radial increment [49]. For 3- to 11-year-old Scots pines, a decrease in the height and radial growth had been observed to reach $7 \%$ to $18 \%$ during the epidemic year and the three subsequent seasons, compared to the long-term average [20].

The effect of damage by forest pathogens on full-rotation profitability can be comparable to or even exceed wind damage effects [50,51], for which various risk scenarios in boreal forests have projected up to a $13 \%$ lower net present value (NPV) compared to the optimised scenarios aiming for maximised NPV and minimised wind risk [39]. Similar to wind damage, the effect of pathogens, such as L. seditiosum, is a natural disturbance that alters the flow of forest goods, thus forcing management to adapt to mitigate the economic risks $[19,22]$. Regardless of management regime, EAA in our simulations tended to decrease with increasing damage severity (Figures 4 and 5, Table S4). Nevertheless, simulations assumed no further growth increment reduction after the age of 17 years and thus did not account for the possible slower future growth of the severely damaged group. Since Lophodermium damage may have a longer negative impact on growth up to the age of 30 years [20,52], the differences in full rotation productivity and profitability might be even higher. However, the negative effect of the reduced growth due to pathogen attacks even at an early age might have a long-term effect on other stand parameters and the monetary value of the final stand. On average, the estimated EAA from ca. $60 \mathrm{EUR} \mathrm{ha}^{-1} \mathrm{year}^{-1}$ for the group with grades 1 to 2 was reduced by $100 \%$ to almost zero for severely damaged trees (grade 4 to 5) (Figure 4). For the Douglas fir, Pseudotsuga menziesii (Mirb.) Franco in New Zealand, the estimated cumulative reduction in the mean top height, basal area, and stem volume until a stabilized growth rate 14 to 20 years after Swiss needle cast effects (caused by Phaeocryptopus gaeumannii) was reported to reach $25 \%, 27 \%$, and $32 \%$, respectively [53]. For loblolly pine, Pinus taeda L., and slash pine, Pinus elliottii Engelm., the planting stock resistant to fusiform rust (Cronartium quercuum) was estimated to have an increased land expectation value ( $r=6 \%$ ) by $40.2 \%$ to $89.8 \%$ and $6.1 \%$ to $40.3 \%$, respectively, compared to susceptible stands, due to higher volume production [54]. In New Zealand, ca. 50\% defoliation of radiata pine Pinus radiata D. Don at an early age reduced the net present value by $46 \%$ when applying a rate of $6 \%$ [55].

In contrast to wind and fire damage, which are generally followed by salvage logging of dead trees and a desirable shortened rotation, the most appropriate strategy to maximise profitability for 
stands with reduced growth (without massive mortality) after defoliation by needle cast might be an increased rotation length aiming to reach a larger DBH and, hence, a higher stumpage value [22,56]. Our results indicated such a tendency for L. seditiosum damage, since EAA tended to culminate later with increasing needle cast severity (Figure 5). Nevertheless, for all damage levels, the highest EAA was reached earlier than the conventional final harvest age (101 years) when reaching the minimum allowable DBH (on average, at the age of 64 to 97 years; Figure 4).

Thinning is an important tool to reduce financial losses [56]. In our study, simulations with the input density (age 17 years) thinned to 1400 trees ha $^{-1}$ exhibited a higher EAA for even the most severely damaged trees compared to higher density scenarios (Figure 5, Table S4). Although profitability by applying more intensive management in young stand for severely damaged groups could not reach the same levels as a group of resistant trees, early thinning was effective to partly compensate for the reduced growth caused by defoliation [56]. However, following commercial thinnings with moderate intensity (reducing relative stand density from 0.95 to 0.70 ) resulted in a higher EAA than more intensive interaction, reducing relative stand density from 0.95 to 0.60 (Table S4). It is supported by other studies that heavy thinning reduces annual volume increment and hence total yield $[57,58]$.

Overall, silvicultural measures, such as thinning, mitigate the financial consequences of needle cast epidemics; yet, control of this fungal infection is challenging [13]. One possible measure could be breeding for a more-resistant Scots pine. For instance, considerable improvement in the resistance of $P$. radiata to Cyclaneusma needle cast caused by Cyclaneusma minus has been achieved by culling susceptible genotypes when selecting for productivity [27]. Due to breeding activities in the southern USA, the reduction of fusiform rust in the slash pine from $50 \%$ to $36 \%$ has been achieved along with a genetic gain of $25 \%$ to $30 \%$ in forest productivity [59]. In addition, further selection for resistance to fusiform rust is estimated to reduce the optimal harvest age by ca. 20\% [60]. For the radiata pine, the selection for reduced defoliation caused by Dothistroma needle blight is estimated to have a similar effect on profitability as the increased growth on pathogen-free sites [55]. The results indicated a significant genetic effect on Lophodermium needle cast resistance and, hence, the possibility to select and test potentially more-resistant genotypes. It was supported by strong negative correlations $(r=-0.62,-0.70, p<0.01)$ between survival and height at the age of 17 years and the proportion of severely damaged trees (Table 1 ) at the family mean level. Significant effects of provenance and genetic entries on resistance have been reported in earlier studies [18,30-32,47]. The results indicated that, if the risk of needle cast damage could be minimised by applying such measures as the selection of more resistant genotypes, the EAA financial outcome might be improved regardless of the decisions concerning a desirable management regime and final harvest time. Thus, we suggest further analyses of the potential breeding for improved Lophodermium needle cast resistance. Considering the earlier findings and the negative family mean correlations between needle cast damage and growth (Table 1 , Figure 4), higher weights in the selection process could be allocated to the results of progeny trials with observed needle cast damage because height growth of superior families would already likely reflect resistance to the pathogen.

\section{Conclusions}

Lophodermium needle cast negatively affects both tree height and DBH 11 years after a pathogen attack. In long-term simulations, L. seditiosum attacks at an early age had a substantial effect on EAA at the final harvest, which was by an average of $61.5 \mathrm{EUR} \mathrm{ha}{ }^{-1}$ or $100 \%$ lower for severely damaged trees compared to the unaffected trees, applying a $2 \%, 3 \%$, and $4 \%$ interest rate. Later EAA culmination for more damaged trees suggested a longer rotation time for more affected stands. However, more intensive early thinning may partly compensate for the reduction in growth and reduce the final harvest age, hence improving the financial outcome of already-affected stands. As indicated by the significant genetic effect on needle cast damage, the selection of more-resistant genotypes could potentially be included in Scots pine breeding activities. 
Supplementary Materials: The following are available online at http://www.mdpi.com/1999-4907/11/7/718/s1, Supplement 1: Applied growth modelling system, Table S1: Commercial thinning schedule (removed volume, $\mathrm{m}^{3} \mathrm{ha}^{-1}$ ) in simulated stands with different initial densities and thinning criteria, Table S2: Forest management operations and their costs used in the simulations, Table S3: Assortment prices at different price levels, Table S4: Equal annual annuity (EAA) for different Lophodermium needle cast damage levels in simulated management scenarios of various initial density at the age of 17 years, and different thinning regimes applied.

Author Contributions: Conceptualisation, Ā.J.; methodology, Ā.J. and J.D.; formal analysis, J.D. and U.N.; data curation, Ā.J.; writing_-original draft preparation, P.Z. and Ā.J.; writing_review and editing, U.N. and J.D.; project administration, Ā.J. All authors have read and agreed to the published version of the manuscript.

Funding: This research was funded by LVM, project number 5.5._002t_101.15.57.

Acknowledgments: Analysis carried out in LVM project "Forest management risks: prognosis and minimisation" (No. 5.5._002t_101.15.57).

Conflicts of Interest: The authors declare no conflict of interest.

\section{References}

1. Kellomäki, S.; Peltola, H.; Nuutinen, T.; Korhonen, K.T.; Strandman, H. Sensitivity of managed boreal forests in Finland to climate change, with implications for adaptive management. Philos. Trans. R. Soc. B Biol. Sci. 2008, 363, 2341-2351. [CrossRef]

2. Mullett, M.S.; Brown, A.V. Effect of dothistroma needle blight on needle and shoot lengths. For. Pathol. 2018, 48, 1-7. [CrossRef]

3. Bednářová, M.; Dvořák, M.; Janoušek, J.; Jankovský, L. Other foliar diseases of coniferous trees. In Infectious Forest Diseases; CABI Publishing: Wallingford, UK, 2013; pp. 458-487. ISBN 9781780640402.

4. Desprez-Loustau, M.L.; Robin, C.; Reynaud, G.; Déqué, M.; Badeau, V.; Piou, D.; Husson, C.; Marçais, B. Simulating the effects of a climate-change scenario on the geographical range and activity of forest-pathogenic fungi. Can. J. Plant Pathol. 2007, 29, 101-120. [CrossRef]

5. La Porta, N.; Capretti, P.; Thomsen, I.M.; Kasanen, R.; Hietala, A.M.; Von Weissenberg, K. Forest pathogens with higher damage potential due to climate change in Europe. Can. J. Plant Pathol. 2008, 30, 177-195. [CrossRef]

6. Sturrock, R.N.; Frankel, S.J.; Brown, A.V.; Hennon, P.E.; Kliejunas, J.T.; Lewis, K.J.; Worrall, J.J.; Woods, Ā.J. Climate change and forest diseases. Plant Pathol. 2011, 60, 133-149. [CrossRef]

7. Drenkhan, R.; Tomešová-Haataja, V.; Fraser, S.; Bradshaw, R.E.; Vahalík, P.; Mullett, M.S.; Martín-García, J.; Bulman, L.S.; Wingfield, M.J.; Kirisits, T.; et al. Global geographic distribution and host range of Dothistroma species: a comprehensive review. For. Pathol. 2016, 46, 408-442. [CrossRef]

8. Wyka, S.A.; McIntire, C.D.; Smith, C.; Munck, I.A.; Rock, B.N.; Asbjornsen, H.; Broders, K.D. Effect of climatic variables on abundance and dispersal of lecanosticta acicola spores and their impact on defoliation on eastern white pine. Phytopathology 2018, 108, 374-383. [CrossRef]

9. McLaughlin, J.; Šica, L. Growing pine in Latvia: Pathological considerations. Proc. Latv. Acad. Sci. 1993, 7, $49-55$.

10. Lilja, A.; Lilja, S.; Kurkela, T.; Rikala, R. Nursery practices and management of fungal diseases in forest nurseries in Finland. A review. Silva Fenn. 1997, 31, 79-100. [CrossRef]

11. Stenström, E.; Arvidsson, B. Fungicidal control of Lophodermium seditiosum on Pinus sylvestris seedlings in Swedish forest nurseries. Scand. J. For. Res. 2001, 16, 147-154. [CrossRef]

12. Drenkhan, R.; Hanso, M. Recent invasion of foliage fungi of pines (Pinus spp.) to the Northern Baltics. For. Stud./Metsanduslikud Uurim. 2009, 51, 49-64. [CrossRef]

13. Raitelaitytė, K.; Rutkauskas, A.; Radzijevskaja, J.; Žukauskienė, J.; Markovskaja, S.; Paulauskas, A. The fungal pathogens causing diseases in pines. Biologija 2017, 62. [CrossRef]

14. Sierota, Z.; Grodzki, W.; Szczepkowski, A. Abiotic and biotic disturbances affecting forest health in Poland over the past 30 years: Impacts of climate and forest management. Forests 2019, 10, 75. [CrossRef]

15. Diwani, S.A.; Millar, C.S. Pathogenicity of three Lophodermium species on Pinus sylvestris L. Eur. J. For. Pathol. 1987, 17, 53-58. [CrossRef]

16. Ostry, M.E. Effect of Lophodermium seditiosum on Growth of Pine Nursery Seedlings in Wisconsin. Plant Dis. 1989, 73, 798. [CrossRef] 
17. Kulman, H. Effects of Artificial Defoliation of Pine on Subsequent Shoot and Needle Growth. For. Sci. 1965, 11,90-98. [CrossRef]

18. Jansons, A. A Neimane, U.; Polmanis, K.; Zaluma, A.; Gaitnieks, T.; Baumanis, I. Cumulative effect of needle cast on scots pine saplings. For. Stud. 2016, 65, 5-15. [CrossRef]

19. Montagné-Huck, C.; Brunette, M. Economic analysis of natural forest disturbances: A century of research. J. For. Econ. 2018, 32, 42-71. [CrossRef]

20. Hanso, M.; Drenkhan, R. Lophodermium needle cast, insect defoliation and growth responses of young Scots pines in Estonia. For. Pathol. 2012, 42, 124-135. [CrossRef]

21. Lindner, M.; Maroschek, M.; Netherer, S.; Kremer, A.; Barbati, A.; Garcia-Gonzalo, J.; Seidl, R.; Delzon, S.; Corona, P.; Kolström, M.; et al. Climate change impacts, adaptive capacity, and vulnerability of European forest ecosystems. For. Ecol. Manage. 2010, 259, 698-709. [CrossRef]

22. Macpherson, M.F.; Kleczkowski, A.; Healey, J.R.; Hanley, N. The effects of disease on optimal forest rotation: A generalisable analytical framework. Environ. Resour. Econ. 2016, 70, 565-588. [CrossRef]

23. Hanso, M.; Drenkham, R. Retrospective Analysis of Lophodermium seditiosum Epidemics in Estonia. Acta Silv. LIgn. Hung. 2007, Spec. Edit, 31-45.

24. Kanaskie, A. Lophodermium needle cast of Scotch pine. In Growing Healthy Seedlings: Identification and Management of Pests in Northwest Forest Nurseries; Hamm, P.B., Hansen, E.M., Campbell, S.J., Eds.; Forest Pest Management, U.S. Department of Agriculture, Forest Service, Pacific Northwest Region; and Forest Research Laboratory, College of Forestry, Oregon State University: Corvallis, OR, USA, 1990; p. 34.

25. Berlin, M.; Lönnstedt, L.; Jansson, G.; Danell, Ö.; Ericsson, T. Developing a Scots pine breeding objective: A case study involving a Swedish sawmill. Silva Fenn. 2010, 44, 643-656. [CrossRef]

26. Krakau, U.-K.; Liesebach, M.; Aronen, T.; Lelu-Walter, M.-A.; Schneck, V. Scots Pine (Pinus sylvestris L.); Springer: Dordrecht, The Netherlands, 2013; pp. 267-323.

27. Suontama, M.; Li, Y.; Low, C.B.; Dungey, H.S. Genetic improvement of resistance to cyclaneusma needle cast in pinus radiata. Can. J. For. Res. 2019, 49, 128-133. [CrossRef]

28. Barzdajn, W.; Kowalkowski, W.; Chmura, D.J. Variation in growth and survival among European provenances of pinus sylvestris in a 30-year-old experiment. Dendrobiology 2016, 75, 67-77. [CrossRef]

29. Rieksts-Riekstinšs, R.; Zeltinšs, P.; Baliuckas, V.; Bruna, L.; Zaluma, A.; Kapostinš, R. Pinus sylvestris breeding for resistance against natural infection of the fungus heterobasidion annosum. Forests 2020, 11, 23. [CrossRef]

30. Squillace, A. Genetic Variation and Breeding of Scots Pine in the Netherlands. For. Sci. 1975, 21, $341-352$. [CrossRef]

31. Neimane, U.; Polmanis, K.; Zaluma, A.; Klavina, D.; Gaitnieks, T.; Jansons, A. Damage caused by Lophodermium needle cast in open-pollinated and control-crossed progeny trials of Scots pine (Pinus sylvestris L.). For. Chron. 2018, 94, 155-161. [CrossRef]

32. Stephan, B.R.; Krusche, D. Genetic Variation of Resistance to Lophodermium Needle Cast in Scots Pine Progenies of Intraprovenance and Interprovenance Crossings1. In Proceedings of the Recent Research on Conifer Needle Diseases: Conference Proceedings, Gulfport, MS, USA, 14-18 October 1984; Petterson, G.W., Ed.; US Department of Agriculture, Forest Service: Washington, DC, USA, 1986.

33. Ranta, H.; Pulkkinen, P.; Neuvonen, S. Susceptibility of six scots pine clones to the pathogenic fungus gremmeniella abietina. Scand. J. For. Res. 2000, 15, 7-12. [CrossRef]

34. Schelhaas, M.J.; Nabuurs, G.J.; Schuck, A. Natural disturbances in the European forests in the 19th and 20th centuries. Glob. Chang. Biol. 2003, 9, 1620-1633. [CrossRef]

35. Jactel, H.; Nicoll, B.C.; Branco, M.; Gonzalez-Olabarria, J.R.; Grodzki, W.; Långström, B.; Moreira, F.; Netherer, S.; Christophe Orazio, C.; Piou, D.; et al. The influences of forest stand management on biotic and abiotic risks of damage. Ann. For. Sci. 2009, 66. [CrossRef]

36. Seidl, R.; Fernandes, P.M.; Fonseca, T.F.; Gillet, F.; Jönsson, A.M.; Merganičová, K.; Netherer, S.; Arpaci, A.; Bontemps, J.D.; Bugmann, H.; et al. Modelling natural disturbances in forest ecosystems: A review. Ecol. Modell. 2011, 222, 903-924. [CrossRef]

37. Seidl, R.; Schelhaas, M.J.; Rammer, W.; Verkerk, P.J. Increasing forest disturbances in Europe and their impact on carbon storage. Nat. Clim. Chang. 2014, 4, 806-810. [CrossRef] [PubMed]

38. Thürig, E.; Hagedorn, F.; Lindroth, A. Influence of storm damage on the forest carbon balance. In Living with the Storm Damage; Gardiner, E., Schuck, A., Schelhaas, M.-J., Orazio, C., Blennow, K., Nicoll, B., Eds.; European Forest institute: Joensuu, Finland, 2013; pp. 47-55. 
39. Zubizarreta-Gerendiain, A.; Pukkala, T.; Peltola, H. Effects of wind damage on the optimal management of boreal forests under current and changing climatic conditions. Can. J. For. Res. 2017, 47, 246-256. [CrossRef]

40. Bušs, K. Meža ekoloóija un tipoloǵija [Forest Ecology and Typology]; Zinātne: Rīga, Latvia, 1981.

41. R Core Team R: A language and environment for statistical computing. 2019. Available online: https://www. gbif.org/tool/81287/r-a-language-and-environment-for-statistical-computing (accessed on 22 January 2020).

42. Donis, J.; Šnepsts, G. Novēloti koptu vienvecuma eglu audžu apsaimniekošanas alternatīvas un to ekonomisks izvērtējums [Management alternatives and their financial analysis for even-age Norway spruce stands with delayed thinnings]. In Vienvecuma eglu meži Latvijā; Jansons, J., Ed.; LVMI Silava: Salaspils, Latvia, 2019; pp. 71-98. ISBN 978-9984-14-853-3.

43. Ozolins, R. Forest stand assortment structure analysis using mathematical modelling. For. Stud. Uurim. 2002, 37, 33-42.

44. Central Statistical Bureau of Latvia: Average purchase prices of wood. 2018. Available online: https://www.csb.gov.lv/en/statistics/statistics-by-theme/agriculture/forestry/tables/meg050/averagepurchase-prices-wood-eur-m3-excluding-vat (accessed on 17 December 2019).

45. Klempered, W.D. Forest Resource Economics and Finance; McGraw-Hill Series in Forest Resources: Blacksburg, VA, USA, 1996.

46. Stenström, E.; Ihrmark, K. Identification of Lophodermium seditiosum and L. pinastri in Swedish forest nurseries using species-specific PCR primers from the ribosomal ITS region. For. Pathol. 2005, 35, 163-172. [CrossRef]

47. Martinsson, O. Testing Scots Pine for Resistance to Lophodermium Needle Cast. Stud. For. Suec. 1979, 63.

48. Garrett, K.A.; Nita, M.; De Wolf, E.D.; Esker, P.D.; Gomez-Montano, L.; Sparks, A.H. Plant Pathogens as Indicators of Climate Change. In Climate Change: Observed Impacts on Planet Earth: Second Edition; Elsevier Inc.: Amsterdam, The Netherlands, 2016; pp. 325-338. ISBN 9780444635242.

49. Kurkela, T.; Drenkhan, R.; Vuorinen, M.; Hanso, M. Growth response of young Scots pines to needle loss assessed from productive foliage. For. Stud./Metsanduslikud Uurim. 2009, 50, 5-22. [CrossRef]

50. Donis, J.; Saleniece, R.; Krisans, O.; Dubrovskis, E.; Kitenberga, M.; Jansons, A. A Financial Assessment of Windstorm Risks for Scots Pine Stands in Hemiboreal Forests. Forests 2020, 11, 566. [CrossRef]

51. Samariks, V.; Krisans, O.; Donis, J.; Silamikele, I.; Katrevics, J.; Jansons, A. A cost-benefit analysis of measures to reduce windstorm impact in Norway spruce (Picea abies L. Karst.) stands: A case study in Latvia. Forests 2020, 11, 576. [CrossRef]

52. Kowalski, T. Interrelationships among Lophodermium seditiosum, L. pinastri and Cyclaneusma minus in pine plantations (Pinus sylvestris L.) in Poland. In Proceedings of the Recent Research on Foliage Diseases, Carlisle, PA, USA, 29 May-2 June 1989; Merrill, W., Ostry, M.E., Eds.; USDA: Washington, DC, USA, 1990; pp. 13-18.

53. Kimberley, M.O.; Hood, I.A.; Knowles, R.L. Impact of Swiss needle-cast on growth of Douglas-fir. Phytopathology 2011, 101, 583-593. [CrossRef] [PubMed]

54. Brawner, J.T.; Carter, D.R.; Huber, D.A.; White, T.L. Projected gains in rotation-age volume and value from fusiform rust resistant slash and loblolly pines. Can. J. For. Res. 1999, 29, 737-742. [CrossRef]

55. Ivković, M.; Baltunis, B.; Gapare, W.; Sasse, J.; Dutkowski, G.; Elms, S.; Wu, H. Breeding against dothistroma needle blight of radiata pine in Australia. Can. J. For. Res. 2010, 40, 1653-1660. [CrossRef]

56. Petucco, C.; Andrés-Domenech, P. Land expectation value and optimal rotation age of maritime pine plantations under multiple risks. J. For. Econ. 2018, 30, 58-70. [CrossRef]

57. Mäkinen, H.; Hynynen, J.; Isomäki, A. Intensive management of Scots pine stands in southern Finland: First empirical results and simulated further development. For. Ecol. Manag. 2005, 215, 37-50. [CrossRef]

58. Mäkinen, H.; Isomäki, A. Thinning intensity and growth of Scots pine stands in Finland. For. Ecol. Manag. 2004, 201, 311-325. [CrossRef]

59. Randolph, K.C. Status of fusiform rust incidence in slash and loblolly pine plantations in the southeastern United States. Gen. Tech. Rep. South. Res. Station. USDA For. Serv. 2016, 212, 53-59.

60. Susaeta, A. Implications of future risk of fusiform rust on optimal forest management of even-aged slash pine plantations. For. Pol. Econ. 2020, 116, 102183. [CrossRef]

(C) 2020 by the authors. Licensee MDPI, Basel, Switzerland. This article is an open access article distributed under the terms and conditions of the Creative Commons Attribution (CC BY) license (http://creativecommons.org/licenses/by/4.0/). 